\title{
Contractors Perceptions of Effects of Project Overhead Costs on Building Project Performance in South-South of Nigeria
}

\author{
Ujene, A.O. ${ }^{*}$, Idoro, G.I. ${ }^{2}$, and Odesola, I.A. ${ }^{1}$
}

\begin{abstract}
This study assesses 12 types of project overhead costs, 6 methods of allocation and 15 factors which affect project overhead costs in South-South of Nigeria. The objective is to compare small and medium contractors' perception of the methods of allocation, factors affecting project overhead costs and the effect of the types of project overhead costs on cost, time and quality of the projects. Data were obtained through 501 structured questionnaires administered to small and medium contractors and analysed using mean item score, and Mann-Whitney U test. The results reveal that contractors perceive that supervision costs, cost of rework, equipment management costs, general field expenses, and temporary works costs were prominent overheads affecting cost, time, and quality performance of projects. There is no difference in the contractors' perceptions of issues affecting overhead costs. It is recommended that contractors should give adequate priority to significant project overheads and their influencing factors.
\end{abstract}

Keywords: Building projects, contractors, perception, project overhead costs, project performance.

\section{Introduction}

The activities of construction industry include the procurement of goods and services as well as the execution of a variety of physical structures and infrastructures [1]. The products of the industry take huge amount of costs which require prudent management. One of such costs is overhead costs, which are usually categorized into project and company overheads. Project overhead is the cost specific to running a project as a whole, but not specific to a trade, work item or performance of any particular element [2,3]. Company overheads, also called general and administrative overhead (G \& A overhead), includes all costs incurred by the construction firm in maintaining the firm in business and supporting the production process but are not directly related to a specific project. It varies from 8 to 30 percent of the total construction volume depending upon market conditions, nature of the project, and the internal objectives of the company [4]. All indirect materials, indirect labour plus others such as company depreciation on plant and equipment, insurance, utilities and so on, come under company overhead classification [5].

\footnotetext{
1, Department of Building, Faculty of Environmental Studies, University of Uyo, Uyo, Akwa-Ibom State, NIGERIA

2 Department of Building, Faculty of Environmental Sciences, University of Lagos, Akoka, Lagos, NIGERIA.

*Corresponding Author e-mail: ujenetony@yahoo.com
}

Note: Discussion is expected before November, $1^{\text {st }} 2013$, and will be published in the "Civil Engineering Dimension" volume 16, number 1, March 2014

Received 13 July 2012; revised 14 April 2013; accepted 28 May 2013
The component of project overhead costs vary significantly ranging between 11 and 20 percent or more of the total direct costs, depending on the project size, type, location, the consultants involved and the client [2].

Accurate estimation requires a contractor to cover all direct and indirect or overhead costs, which constitute the two major types of expenses in construction. Estimating direct cost has received most of the attention and reasonable results have been achieved in accurately estimating material, labour, and equipment costs. However many contractors face difficulty in maintaining an acceptable rate of return due to cost overrun which can be blamed for many reasons on high overhead. These costs according to some studies vary from one company to another and always constitute a significant sum of any construction firm's expenses [6]. Some studies opined that it ranges from $7.5 \%$ to $35 \%$ of the total costs depending on the nature of the project [7]. Contractors who choose to go the easy way and recover project overhead costs through setting a percentage of direct costs may end up overor under-estimating these costs which may lead to incorrect bid [2].

Among the reasons which necessitate examining overhead cost is the fact that as the construction industry increasingly employs sophisticated technologies, the percentage of overhead cost to total production costs increases, as today contractors have to pay the costs for the technical advancement utilized in the production process which cannot be directly assigned to a specific work item. An example 
is the cost of utilizing advanced computers to control production operations, to prepare project schedules, to prepare drawings, or the expenses needed to perform some of the tests [8]. However, the amount allocated to the various types of project overhead costs depends on the contractor, the method and accuracy of estimation, which influences the final performance of the project.

This paper assesses contractors' perceptions of the effects of the differing amounts of project overhead costs on performance of building project in SouthSouth geo-political zone of Nigeria with the view to facilitating improved cost management for better performance of building project in the study area. The emphasis of this improved cost management in the South-South zone is consequent upon the recent increased tempo in construction activities as a result of the federal government and private sector response to the zones agitation for sustainable development. This has also led to the creation of Niger Delta Ministry in recognition of the immense contribution of the region to the economic sustainability of the country.

\section{Aim and Objectives of the Study}

The aim of this study is to provide a basis for accurate estimation, allocation and control of project overhead costs with a view to improving the performance of building construction project in SouthSouth geo-political zone of Nigeria. The objectives are as follows:

1) to evaluate small and medium size contractors' perception of the effects of the amounts of different project overhead costs on performance of projects.

2) to evaluate the contractors' perceptions of the factors which affect the amounts of project overhead costs in the study area, and

3) to evaluate the contractors' perceptions of the level of use of project overhead cost allocation methods by companies in South-South of Nigeria.

The null hypotheses formulated for the research are:

1) There is no significant difference in the perceptions of small and medium contractors concerning the effect of types project overhead costs on the performance of building project in the study area.

2) There is no significant difference in the perceptions of small and medium contractors concerning the relative effect of project overhead allocation factors on amount of project overhead costs in the zone.

3) There is no significant difference in the perceptions of small and medium contractors concerning the methods of allocating project overhead in South-South of Nigeria.
The result of this work will assist in improving accurate cost estimation of firm which is essential in the measurement of a firm's efficiency and profit recognition. Efficiency is a measure of the relationship between resources consumed and products produced. If resources used to produce a specific product are not accurately included, then product pricing will not be correct, profit recognition will not be reachable and a firm's efficiency cannot be measured [9]. Furthermore the study will assist in improving the performance of building projects, and hence reduce such problems as; construction cost overrun, delay and abandonment of project, loss of profit, bankruptcy and insolvency by contractors. Other associated problems to be solved are; loss of quality, clients' dissatisfaction and disputes among stakeholders [10,11].

\section{Classification of Project Overhead Costs}

Project overhead or indirect costs which are too specific to a project, but not specific to a trade or work item [12] are usually detailed at the time of estimation of project costs and the estimator must be conversant with the various sources and classification of project overhead costs [7]. The study noted that project overheads which can be classified as fixed, variable, or semi variable overheads are generally made up of the production overheads, external support services costs, administrative overheads and home office overheads depending on the policy and characteristics of the company involved.

The study further divided these costs into, supervision costs, indirect personnel costs, temporary works and services costs, general field expenses, equipment management costs, small tools and consumables, housing costs, catering costs, mobilization and demobilization costs, company taxes and insurance. Similarly, types of project overhead costs is also identified to include; supervision costs, insurance, taxes and bonds, estimate contingency and unforeseen conditions, temporary constructions, cost of rework, financing cost, profit, equipment costs, and others [2].

\section{Allocating/Estimating Project Overhead Costs}

The estimator uses various methods to allocate the overhead costs into the production costs. These costs can be charged to the direct costs on a proportionate basis, some of the overhead costs are priced under the preliminary items in the Bill of Quantities (BOQ) and the remaining distributed proportionately to the remaining items of the BOQ. Another method is to divide the overhead costs under indirect labour costs, indirect material costs, indirect equipment costs and 
indirect other expenses, and then distribute these costs to the production direct costs using predetermined criteria. It has also been observed that some contractors use the expected duration needed to construct the project as an allocation base. The argument used was that most of overhead costs are a function of time [13]. Thus, the longer the project takes to be completed, the more overhead costs are incurred. Although this method is not widely used, it could significantly improve the accuracy in overhead allocation provided estimated duration is right. Studies have established that for more accuracy in cost estimation an adequate project plan has to be prepared that includes the best combination of the resources needed to finish the job in optimal time [2]. This optimal time can then serve as a base for estimating many project overhead costs. It has also been noted that for better accuracy project overhead costs can be allocated using Activity Base Costing (ABC). This method measures a firm's consumption of resources by using multiple activities causing cost referred to as cost drivers [7].

\section{Factors Affecting the Project Overhead Costs}

Contractors final decision in determining the level or amount of project overhead cost is usually affected by several factors, namely; the nature of the contract, the size and complexity of the project, the contractor's need for work, cash availability of the contractor, the contractor's experience with the client, the degree to which subcontractors services are needed, or the number of contractors competing to win the project which may not be known at bidding time [2,3]. Other factors include payment schedule and client's strictness in supervision, all in order of rank from the first to the last order of effect. Some factors have also been identified to contribute to building construction site overhead cost in the Egyptian construction market. The factors in order of importance are; project duration, project size/ contract value, project type, special site preparation requirements and project location. Others are construction firm category, project need for extraman power, type-nature of client, type of contract, and contractor-joint venture [14].

\section{Contractors Type/Firm Size}

Most studies have tried to classify firms either by annual turnover or by the number of permanent employee in their payroll. Firms have been classified based on the above into four categories namely; Micro/Cottage, Small, Medium, and Large firms $[15,16]$.

The classification in the construction industry tends to slightly differ from the above general classifica- tion, as contractors in the construction industry are categorised as being indigenous or foreign, or according to the number of permanent employee in their payroll or according to the category of registration [17]. This study, for simplicity, adopted the classification by the number of permanent employee and by category of registration for its evaluation. By this classification, construction firms are classified into three major categories namely: large sized; medium sized, and small sized firms [18]. While the small sized firms deal mainly with minor works, repair and maintenance of buildings in a particular locality, the large sized firms, on the other hand, deal with a wide range and size of activities on a national or even global basis. Contractors can be categorised into different sizes using number of permanent employee, namely; 0-49 employees = small contractors, 50-249 employees $=$ medium, $>250$ employees $=$ large contractors [19]. This study focuses on small and medium sized construction firms, while excluding the large firms because there are few number of them mostly owned by expatriates and their operations are mostly based on civil engineering projects and few massive building projects within major cities in the study area [17].

\section{The Concept of Performance in Construction}

Performance has been generally described as the degree of achievement of certain effort or undertaking, or more literally as how well or badly something is done. Project performance is related to the prescribed goals or objectives which form the project parameters [11]. Project performance viewed from project management perspective, is seen as being all about meeting or exceeding stakeholders' needs and expectations from a project which invariably involves placing consideration on major project elements of time, cost, quality, health and safety, profitability, productivity and others [11]. It has been pointed out that, in today's highly competitive and uncertain business environment, the client who is the major stakeholder, want speedier delivery of their project with early start of construction work, certainty of performance in term of cost, quality and time, value for money for their investment, minimal exposure to risk, and early confirmation of design and price or cost [20]. It has also been noted that it is also commonly agreed among researchers that client needs are generally in terms of time, cost and quality. Usually, project success is measured on these terms [21].

The aim of any project manager is to achieve project within predefined time, cost, and quality constraints [22]. These three factors play significant roles in achieving project objectives and ascertaining the level of success of a project. The inaccurate esti- 
mation and allocation of cost have been established to lead to cost overrun, delay or time overrun, abandonment, and clients' dissatisfaction [23]. However, the effect of non inclusion of the overhead cost for items like small tools and consumables on cost or time overrun, may not be the same as that which non or in adequate estimation of supervision costs or indirect personnel costs will have on cost or time overrun, because some project overhead items attract more costs than others and hence influence costs and delay in accordance with their magnitude. Moreover, the management priority on these items may affect their outcomes.

\section{The Study Area}

The South-South geo-political zone is one of the six officially grouped geopolitical zones based on linguistic affinity, contiguity and cultural affiliation for ease of administration. The South-South geopolitical zone of Nigeria coincides approximately to the NigerDelta area of the country [24]. The South-South geopolitical zone which is identified with sandy deltaic coastal plain of the Guinea coast is made up of six out of the nine in the Niger Delta zone, namely; Akwa Ibom, Bayelsa, Cross River, Delta, Edo, and Rivers. Most of the states have low-lying flat landscape predominated with coastal plain sediment which are marine, deltaic, estuarine, lagoon and Fluvial-lacustrine material [25].

The six states that make up the South-South geopolitical zone of Nigeria have a total of 185 Local Government Areas [26]. This region has estimated population of about 21 million people from 2006 census [27]. The zone has about 40 different ethnic groups, speaking about 250 dialects spread across 5000 communities and covering a land mass of about 80,000 square kilometres [26]. Numerous problems identified confronting the area are namely; environmental degradation, poor health facilities, inadequate housing, poor transport facilities, infertile soil as a result of oil exploration, insecurity, poor education facilities, poor power supply, lack of potable drinking water, unemployment and poverty in the face of increasing population, oil exploration and exploitation activities [24]. This zone therefore deserves the sustainable development intended through the creation of the Ministry for Niger Delta Affairs on September 10, 2008 with a twin mandate of focusing on infrastructure development and youth empowerment [28].

\section{Research Methods}

This study adopted the exploratory survey design approach that involves focus group discussion and the use of structured questionnaires. The population of the study consists of small and medium size contractors involved in the execution of educational and administrative public buildings in the SouthSouth zone. The theoretical population of the study could not be defined because of lack of reliable statistics. A pilot survey was therefore conducted in early 2011. From the pilot survey, 457 small size contractors and 44 medium sized contractors were identified in the study area and adopted as the study population.

The variables used for the study were categorised into five groups, namely: types of project overhead costs, methods of allocation of project overhead, project overhead allocation factors, project performance criteria and contractor types. Types of project overhead costs consists of twelve types of project overhead costs, methods of allocation of project overhead consist of seven methods, project overhead allocation factors consist of fifteen factors which were identified from literature search and focus group discussion.

The project performance criteria consist of three most prominent criteria for evaluating the performance of projects namely; cost, time, and quality. From the literatures, it was discovered that the two categories of contractors mostly involved in the execution of educational and administrative buildings in the study area are namely: small and medium sized contractors. Hence small and medium sized contractors constituted the variables of contractor type. Data on the types of project overhead costs and the effects of the fifteen project overhead allocation factors were collected from the contractor types that constituted the respondents of the study using structured questionnaires. The effect of the amount of various project overhead costs on the performance of a project (using cost, time, and quality criteria) and the effect of the factors on the amounts of project overhead costs as well as the evaluation of the level of use of the methods of allocation were measured on a five point Likertscale, namely: nil, low, moderate, high, and very high. The scales were scored as follows: nil $=1$, low $=2$, moderate $=3$, high $=4$, and very high $=5$. From the 501 samples of questionnaire administered on the study population, 406 were completed. This consists of 370 small contractors and 36 medium contractors selected by stratified random sampling technique to form the study sample. This figures represented response rates of $80.9 \%$ for small contractors and $81.8 \%$ for medium contractors. The sampling technique ensured that the sample covered the two categories of contractors and the six states in the study area.

Data collected were processed using Statistics Package for Social Sciences (SPSS) version 17 [28]. The analyses were done to determine the effects of 
the factors on project overhead costs using Mean Score (MS) of each item to evaluate the level of influence which the factor has on the selected performance indicator and the difference in the perceptions of the small and medium size contractors using Mann Whitney U test. MS was derived as the total score divided by the number of respondents for each factor. The significance of the effect of the factors were determined using a baseline of $\mathrm{MS}=2.5$. Based on this baseline, factors with $\mathrm{MS} \geq 2.5$ are regarded as having significant effect while factors with MS $<2.5$ have insignificant effect.

\section{Results and Discussion of Findings}

The results obtained from the analysis of data collected are presented as follows:

\section{Characteristics of Respondents used for the Study}

The characteristics of the contractors that supplied the data used for the study were analysed for an understanding of the parties whose perceptions were investigated. For this purpose, five characteristics namely: type of contractor, registration category, number of permanent employee in the firm, managerial capability, and the years of experience were selected. The percentages of the respondents in each sub-variable were analysed and presented in Table 1.

Table 1 shows that majority of the contracting firms that were used as respondents were small size firms representing $91.1 \%$ of the total respondents. The table also shows that the entire small contractors used were all indigenous representing $91.1 \%$, of the total contractors sampled for the study, while the indigenous contractors among the medium size represented $7.4 \%$ with very few expatriate contractors (1.5\%). The table also shows that majority of the small contractors execute projects ranging from 0-50 million Naira, while majority of the medium size contractors execute projects ranging from 0-250 million Naira. Table 1 also shows that majority of both the small and medium size contractors have moderately adequate managerial capability. The descriptive result also show that majority of the small contractors have 1-10 years experience, while majority of the medium contractors have 1-15 years experience in the construction industry.

Table 1. Descriptive Results of Characteristics of Respondents used for the Study

\begin{tabular}{|c|c|c|c|c|c|c|}
\hline \multirow{2}{*}{ Characteristics of contractors } & \multicolumn{2}{|c|}{ Small contractors } & \multicolumn{2}{|c|}{ Medium contractors } & \multirow{2}{*}{ Small \% total } & \multirow{2}{*}{ Medium \% total } \\
\hline & No & $\%$ & No & $\%$ & & \\
\hline \multicolumn{7}{|l|}{ Type of Contractor } \\
\hline Indigenous & 370 & 100 & 30 & 83.3 & 91.1 & 7.4 \\
\hline Expatriate & 0 & 0 & 6 & 19.7 & 0 & 1.5 \\
\hline Total & 370 & 100 & 36 & 100 & 91.1 & 8.9 \\
\hline \multicolumn{7}{|l|}{ Registration Category } \\
\hline 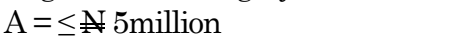 & 205 & 55.4 & 4 & 11.1 & 50.5 & 1.0 \\
\hline $\mathrm{B}=\leq \mathbb{N} 50$ million & 163 & 44.1 & 22 & 61.1 & 40.1 & 5.4 \\
\hline 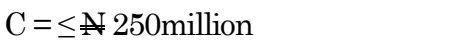 & 2 & 0.5 & 10 & 27.8 & 0.5 & 2.5 \\
\hline $\mathrm{D}=>250$ million & 0 & & 0 & & 0 & 0 \\
\hline Total & 370 & 100 & 36 & 100 & 91.1 & 8.9 \\
\hline \multicolumn{7}{|l|}{ Permanent Employee } \\
\hline 1- 49 workers (small) & 370 & 100 & 0 & 0 & 91.1 & 0 \\
\hline $50-249$ workers (medium) & 0 & 0 & 36 & 100 & 0 & 8.9 \\
\hline Total & 370 & 100 & 36 & 100 & 91.1 & 8.9 \\
\hline \multicolumn{7}{|l|}{ Managerial Capability } \\
\hline Inadequate & 0 & 0 & 0 & 0 & & \\
\hline Fairly adequate & 42 & 11.4 & 6 & 16.7 & 10.3 & 1.5 \\
\hline Moderately adequate & 290 & 78.4 & 17 & 47.2 & 71.4 & 4.2 \\
\hline Highly adequate & 36 & 9.7 & 8 & 22.2 & 8.9 & 2.0 \\
\hline Very Highly adequate & 2 & 0.5 & 5 & 13.9 & 0.5 & 1.2 \\
\hline Total & 370 & 100 & 36 & 100 & 91.1 & 8.9 \\
\hline \multicolumn{7}{|l|}{ Years of Experience } \\
\hline $1-5$ years & 144 & 38.9 & 0 & 0 & 35.5 & 0 \\
\hline $6-10$ years & 119 & 32.2 & 4 & 11.1 & 29.3 & 1.0 \\
\hline $11-15$ years & 60 & 16.2 & 8 & 22.2 & 14.8 & 2.0 \\
\hline $16-20$ years & 40 & 10.8 & 15 & 41.7 & 9.8 & 3.7 \\
\hline Above 20 years & 7 & 1.9 & 9 & 25.0 & 1.7 & 2.2 \\
\hline Total & 370 & 100 & 36 & 100 & 91.1 & 8.9 \\
\hline
\end{tabular}




\section{Effects of Types of Overhead Costs on Cost Performance of Building Projects.}

There is a direct relationship between organization efficiency and project costs which include direct and indirect (overhead) costs. From this perspective, efficiency means the ability to convert input to the output with the lowest cost [30]. The project overhead costs are therefore indirect costs employed to ensure organization efficiency which influences the final cost outcome of the project. The effect of the amount of the components of project overheads on cost performance was measured as described in the methods of the study. Data collected on the perceptions of small and medium size contractors concerning the effect of the values of twelve types of project overheads on cost performance were scored, processed, and analysed using Mean score (MS). The results are presented in Table 2.

Table 2 shows that among the small contractors, general field expenses ranked first with MS of 4.33, followed by indirect personnel costs with MS of 4.11. Supervision costs and contingency/unforeseen conditions ranked third and fourth, with MS of 3.82 and 3.66 respectively. The result is an indication that the small contractors perceive that field expenses and indirect personnel costs exerts more influence on overall cost performance, even though they have fewer permanent workers the total cost spent on casual workers and other field expenses may have been perceived to have most significant effect on the overall cost. Among the medium contractors indirect personnel costs ranked first with MS of 4.14, while supervision costs and general field expenses ranked second and third with MS of 4.06 and 3.92 respectively. The perception of the medium sized contractors also shows that indirect personnel costs affects their overall cost due to the fact that they have more workers on their pay roll than the small contractors. In general the study shows that the types of overhead costs which most significantly affect cost performance of building projects are; supervision costs, cost of rework, equipment management costs, general field expenses, and temporary works and services costs. The result supports study by Assaf et al. [2] which rated supervision, equipment, temporary construction, and financing costs as the four most important classifications used for project overheads in Saudi Arabia. The result thus indicates some similarity between Southern Nigerian and Saudi Arabian contractors. The effect of indirect personnel costs, supervision costs and general field expenses may be attributable to the low technological development of Nigerian construction industry leading to huge amount of project overhead on labour related issues like labour management, motivation and insecurity in the area which increase the overall costs of projects [17].

\section{Effects of Types of Overhead Costs on Time Performance of Building Projects.}

Time management is a key factor to success as less time means a better operational efficiency. Generally when project duration is compressed, the project will call for an increase in labour and more productive equipment and require more demanding procurement and construction management and then the cost will increase [30]. The project overhead costs are often times the indirect costs employed to ensure better operational efficiency. This implies that there is a direct relationship between cost of operational efficiency and project duration. The effect of twelve identified types of project overheads on time performance was measured as described in the methods of the study. The results are presented in Table 3.

Table 3 shows that among the small contractors, indirect personnel costs ranked first with MS of 4.61, followed by supervision costs with MS of 4.53. Temporary works and services costs and general field expenses ranked third and fourth, with MS of 3.91 and 3.86 respectively. This result indicates that the small contractors perceive that indirect per-

Table 2. Rank of Contractors Perceptions of Effect of Amount of Various Types of Overhead Cost on Cost Performance

\begin{tabular}{lcccccc}
\hline \multirow{2}{*}{\multicolumn{1}{c}{ Types of overhead costs }} & \multicolumn{3}{c}{ Small contractors' perceptions } & \multicolumn{3}{c}{ Medium contractors' perceptions } \\
\cline { 2 - 7 } & Sum & MS & Rank & Sum & MS & Rank \\
\hline Indirect personnel costs & 1519 & 4.11 & 2 & 149 & 4.14 & 1 \\
Supervision costs & 1412 & 3.82 & 3 & 146 & 4.06 & 2 \\
General field expenses & 1602 & 4.33 & 1 & 141 & 3.92 & 3 \\
Profit & 1278 & 3.45 & 5 & 129 & 3.58 & 4 \\
Company taxes and insurance & 946 & 2.56 & 11 & 126 & 3.50 & 5 \\
Temporary works and services costs & 1269 & 3.43 & 6 & 124 & 3.44 & 6 \\
Contingency and unforeseen conditions & 1354 & 3.66 & 4 & 122 & 3.39 & 7 \\
Equipment management costs & 871 & 2.35 & 12 & 119 & 3.31 & 8 \\
Small tools and consumables & 1218 & 3.29 & 7 & 117 & 3.25 & 9 \\
Housing \& catering costs & 1068 & 2.89 & 10 & 108 & 3.00 & 10 \\
Mobilization and demobilization costs & 1215 & 3.28 & 8 & 107 & 2.97 & 11 \\
Cost of rework & 1207 & 3.26 & 9 & 105 & 2.92 & 12 \\
\hline
\end{tabular}

Number of small contractors $=370$, Number of medium contractors $=36$ 
Table 3. Rank of Contractors Perceptions of Effect of Types of Overhead Costs on Time Performance of Projects

\begin{tabular}{lcccccc}
\hline \multirow{2}{*}{\multicolumn{1}{c}{ Types of overhead costs }} & \multicolumn{3}{c}{ Small contractors' perceptions } & \multicolumn{3}{c}{ Medium contractors' perceptions } \\
\cline { 2 - 7 } & Sum & MS & Rank & Sum & MS & Rank \\
\hline Supervision costs & 1675 & 4.53 & 2 & 165 & 4.58 & 1 \\
Indirect personnel costs & 1704 & 4.61 & 1 & 162 & 4.50 & 2 \\
General field expenses & 1427 & 3.86 & 4 & 158 & 4.39 & 3 \\
Temporary works \& services costs & 1445 & 3.91 & 3 & 154 & 4.28 & 4 \\
Mobilization \& demobilization costs & 1346 & 3.64 & 5 & 146 & 4.06 & 5 \\
Profit & 1301 & 3.52 & 6 & 145 & 4.03 & 6 \\
Contingency \& unforeseen conditions & 1160 & 3.14 & 8 & 135 & 3.75 & 7 \\
Equipment management costs & 1136 & 3.07 & 9 & 130 & 3.61 & 8 \\
Small tools and consumables & 1231 & 3.33 & 7 & 127 & 3.53 & 9 \\
Cost of rework & 995 & 2.69 & 10 & 115 & 3.19 & 10 \\
Company taxes and insurance & 744 & 2.01 & 12 & 111 & 3.08 & 11 \\
Housing \& catering costs & 981 & 2.65 & 11 & 102 & 2.83 & 12 \\
\hline
\end{tabular}

Number of small contractors $=370$, Number of medium contractors $=36$

Table 4. Rank of Contractors Perceptions of Effect of Type of Overhead Cost on Quality Performance

\begin{tabular}{lcccccc}
\hline \multirow{2}{*}{\multicolumn{1}{c}{ Types of overhead costs }} & \multicolumn{3}{c}{ Small contractors' perceptions } & \multicolumn{3}{c}{ Medium contractors' perceptions } \\
\cline { 2 - 7 } & Sum & MS & Rank & Sum & MS & Rank \\
\hline Supervision costs & 1718 & 4.64 & 1 & 152 & 4.22 & 1 \\
Cost of rework & 1411 & 3.81 & 3 & 141 & 3.92 & 2 \\
General field expenses & 1386 & 3.75 & 4 & 135 & 3.75 & 3 \\
Temporary works and services costs & 1369 & 3.70 & 5 & 131 & 3.64 & 4 \\
Equipment management costs & 1566 & 4.23 & 2 & 120 & 3.33 & 5 \\
Profit & 1259 & 3.40 & 8 & 119 & 3.31 & 6 \\
Contingency and unforeseen conditions & 1245 & 3.36 & 9 & 118 & 3.28 & 7 \\
Indirect personnel costs & 1334 & 3.61 & 6 & 116 & 3.22 & 8 \\
Small tools and consumables & 1265 & 3.42 & 7 & 110 & 3.06 & 9 \\
Housing \& catering costs & 1166 & 3.15 & 10 & 108 & 3.00 & 10 \\
Mobilization and demobilization costs & 1130 & 3.05 & 11 & 101 & 2.81 & 11 \\
Company taxes and insurance & 739 & 2.00 & 12 & 99 & 2.75 & 12 \\
\hline Numyyyyyyy
\end{tabular}

Number of small contractors $=370$, Number of medium contractors $=36$

sonnel cost, supervision costs and temporary works costs have the most significant influence on duration of projects. This may be due to the fact that they incur a lot of costs in resolving problems relating to indirect personnel costs and supervision costs which directly or indirectly prolong completion period of their projects. Among the medium contractors supervision costs ranked first with MS of 4.58, while indirect personnel costs and general field expenses ranked second and third with MS of 4.50 and 4.39 respectively. The significance of these costs on duration of projects may be because the medium sized contractors also spend significant amount of money on issues concerning supervision, indirect personnel costs, and general field expenses which sometimes are contentious leading to disputes and contributes to delay in project completion in the study area.

\section{Effects of Types of Overhead Costs on Quality Performance of Building Projects.}

The trade-off between cost and quality is to maximize the profit, hence it is believed that quality is a factor affecting decision making and paying attention to it can make our decision economic [30].
In order to improve quality an organization must take into account the costs associated with achieving quality since the objective of continuous improvement programs is not only to meet customer requirements, but also to do it at the lowest cost. Therefore the quality attained can be influenced by the operational efficiency of the organization, which can be a function of the costs spent on the items of project overhead. The effect of the amount of twelve identified project overheads costs on quality performance was measured and evaluated. The results are presented in Table 4.

Table 4 shows that among the small contractors, supervision costs ranked first with MS of 4.64, followed by equipment management costs with MS of 4.23. Cost of rework and general field expenses ranked third and fourth, with MS of 3.81 and 3.75 respectively. This result shows that supervision costs and equipment management costs among the small contractors most significantly influence the quality of project. Among the medium contractors supervision costs ranked first with MS of 4.22 , while cost of rework and general field expenses ranked second and third with MS of 3.92 and 3.75 respectively. This result shows that the supervision costs and cost of 
rework most significantly influence the quality of project executed by the medium size contractors in the study area. The results of the study may be related to the fact that contractors in the zone mostly incur huge amount of project overhead costs from, supervision, rework and general field expenses, and the process of controlling the costs to increase profit sometimes lead to compromising quality required from the contractors.

\section{Influence of Overhead Costs on Project Performance}

This study has evaluated the level of influence of the various types of project overhead costs on the main indicators of project performance through the assessment of the perception of small and medium size contractors. A general comparison of the perceptions of the contractors on the effect of cost, time and quality shows that contractors have common view of the level to which most of the overhead cost influence cost, time and quality of projects. The results in Tables 2, 3 and 4 show that majority of the project overhead costs have significant influence on project performance with mean scores greater than hypothesized mean of 2.5. However the results show that the small contractors perceive that equipment management costs, company taxes and insurance do not significantly contribute to the performance of their project probably because they hardly use machines, pay taxes and insure works. Although a significant variation in the level of influence of the project overhead costs on project performance is observed with costs of rework which ranked higher for its influence on quality performance, but ranked lower for its influences on cost and time performance. The result of the perception of contractors in this regard may be due to the fact that most of the rework encountered by the contractors are associated to work not properly executed, though it also contributes to increase in cost and time, but it can be noted that most times even when the costs of a work item has been determined based on the quality specification some contractors compromise quality to safe more money than estimated leading to rework. However, such rework costs associated to poor quality only eats up the contractor's profit, while the overtime to rectify a contractor's poor quality is also at his expense as rework costs are not usually budgeted for specifically, except additional works which are measured as variation especially for contracts which are executed on fixed or lump sums.

\section{Respondents Perception on the Effects of Factors Affecting Project Overhead Costs}

The decision of managers of contracting firms to determine the magnitude or amount of the various items of project overhead costs most times are not based on the figures from project estimators but change project overhead rates to higher or lower values depending on their assessment of some factors presented in Table 5. The effect of fifteen identified factors affecting the amount of project overhead costs in general were evaluated and the results presented in Table 5 .

Table 5 shows that almost all the factors have mean score greater than the hypothesized mean of 2.5, except for fraudulent practices and kickbacks with MS less than 2.5. This implies that the contractors perceive that almost all the factors investigated significantly influence the amount of the various types of project overheads by directly or indirectly exerting pressure on the amount of the various

Table 5. Rank of Contractors Perceptions of Factors Affecting Magnitude of Project Overhead Costs

\begin{tabular}{lrrrrrc}
\hline \multirow{2}{*}{ Factors affecting project overhead } & \multicolumn{3}{c}{ Small contractors' perceptions } & \multicolumn{3}{c}{ Medium contractors' perceptions } \\
\cline { 2 - 7 } & Sum & MS & Rank & Sum & MS & Rank \\
\hline Type, size \& policy of construction firm & 1411 & 3.81 & 3 & 170 & 4.72 & 1 \\
Size and complexity of the project & 1695 & 4.58 & 1 & 146 & 4.06 & 2 \\
Location of project & 1566 & 4.23 & 2 & 146 & 4.06 & 2 \\
Payment schedule & 1371 & 3.71 & 5 & 144 & 4.00 & 4 \\
Nature \& type of the contract & 1387 & 3.75 & 4 & 134 & 3.72 & 5 \\
Cash availability of the contractor & 1275 & 3.45 & 7 & 126 & 3.50 & 6 \\
Need for subcontractors services & 1335 & 3.61 & 6 & 126 & 3.50 & 6 \\
Number of contractors competing & 1261 & 3.41 & 9 & 125 & 3.47 & 8 \\
Contractor's experience with client & 1220 & 3.30 & 10 & 124 & 3.44 & 9 \\
Duration of project & 1264 & 3.42 & 8 & 123 & 3.42 & 10 \\
Contractor's need for work & 1220 & 3.30 & 10 & 122 & 3.39 & 11 \\
Type and nature of client & 1167 & 3.15 & 13 & 119 & 3.31 & 12 \\
Type of consultants & 1209 & 3.27 & 12 & 115 & 3.19 & 13 \\
Level of available information & 1131 & 3.06 & 14 & 112 & 3.11 & 14 \\
Fraudulent practices and kickbacks & 741 & 2.00 & 15 & 83 & 2.31 & 15 \\
\hline Nyyyyyyyy
\end{tabular}

Number of small contractors $=370$, Number of medium contractors $=36$ 
project overhead costs. The results of the table also shows that among the small contractors, size and complexity of the project rank first with MS of 4.58, second was location of project with MS of 4.23, while type, size \& policy of construction firm and nature \& type of the contract ranked third and fourth with MS of 3.81 and 3.75 respectively. The result indicates that small contractors perceive that the amounts of project overhead costs are mostly influenced by size, complexity and location of the project. Among the medium size contractors, type, size \& policy of company ranked first with MS of 4.72 , size and complexity of the project and Location of project both ranked second with MS of 4.06 each, while payment schedule and nature \& type of the contract ranked fourth and fifth with MS of 4.0 and 3.72 respectively.

Similar to the small contractors, the medium contractors also perceive that the amounts of project overhead costs are mostly influenced by type, size and policy of company as well as size and complexity and location of project. The study shows that type, size and policy of construction firm, size and complexity of the project, location of project, payment schedule and nature and type of the contract are the top five factors affecting the amount of project overheads in the area. This is also similar to the findings of [2] and [31] in Saudi Arabia and Egypt respectively. The duo similarly observed that project's duration, total contract value, payment schedule, projects type, special site preparation needs, project's location, and the need for work are the top factors that affect the value of the percentage of site overhead costs for building construction projects. This study observes that type, size and policy of construction firm, size and complexity of the project, location of project, payment schedule and nature and type of the contract significantly influence the amount of project overhead costs because the allocation of values of the percentage of project overhead costs for building construction projects by the contractors are based mostly on these five factors, which also influence the total value of the project. Type of consultants, level of available information and fraudulent practices and kickbacks are the factors that were least rated as influencing the percentage of project overhead costs in general for building construction projects in South-South geopolitical zone of Nigeria.

\section{Respondents' Perception of Level of Use of Methods of Allocating Project Overhead Costs}

The level of uses of seven identified methods of allocating project overhead costs were evaluated and the results are presented in Table 6.

Table 6 shows that among the small contractors, the use of preliminary items and bill of quantities in project overhead cost allocation ranked first with MS of 4.63 , followed by allocation of project overhead costs as a proportion of total direct cost with MS of 3.61 , next in the order of rank were allocation of project overhead costs as a proportion of direct material costs and as proportion of direct labour costs. Among the medium size companies, allocation of project overhead costs as a proportion of total direct cost ranked first with MS of 4.72, the use of preliminary items and bill of quantities in project overhead cost allocation ranked second with MS of 4.19 , while allocation of project overhead costs as a proportion of direct material costs and as proportion of direct labour costs ranked third and fourth with MS of 3.31 and 3.19 respectively. The result of the evaluation of the method of allocation shows that majority of the contractors estimate project overhead as proportion of total direct costs and based on preliminary items and $\mathrm{BOQ}$, hence ranking the two methods first and second, similar to the finding of [2]. The result indicates that the $\mathrm{ABC}$ and project duration methods are hardly ever used in the study area due to the low level of awareness of these methods by contractors cost estimators.

\section{Comparison of the Perceptions of the Small and Medium Size Contractors}

In order to ascertain whether or not the two categories of contractors have the same perception about the effect of the amount of various types of

Table 6. Evaluation of Level of Use of Methods of Allocating Project Overhead Costs

\begin{tabular}{lcccccc}
\hline \multirow{2}{*}{\multicolumn{1}{c}{ Methods of allocation }} & \multicolumn{3}{c}{ Small contractors' perceptions } & \multicolumn{3}{c}{ Medium contractors' perceptions } \\
\cline { 2 - 6 } & Sum & MS & Rank & Sum & MS & Rank \\
\hline Proportion of total direct costs & 1336 & 3.61 & 2 & 170 & 4.72 & 1 \\
Preliminary items and BOQ & 1713 & 4.63 & 1 & 151 & 4.19 & 2 \\
Proportion of only direct material costs & 1259 & 3.40 & 3 & 119 & 3.31 & 3 \\
Proportion of only direct labour costs & 1248 & 3.37 & 4 & 115 & 3.19 & 4 \\
Proportion of only direct equipment costs & 1130 & 3.05 & 5 & 112 & 3.11 & 5 \\
Activity Based Costing & 741 & 2.00 & 7 & 83 & 2.31 & 6 \\
Proportion based on project duration & 835 & 2.26 & 6 & 82 & 2.28 & 7 \\
\hline
\end{tabular}

Number of small contractors $=370$, Number of medium contractors $=36$ 
Table 7. Results of Mann Whitney U Tests

\begin{tabular}{|c|c|c|c|}
\hline Comparison of perceptions of Small and Medium contractors & P-value & Decision & Remark \\
\hline $\begin{array}{l}\text { Effect of the types of project overhead costs on the cost performance of } \\
\text { projects }\end{array}$ & 0.729 & & difference not significant \\
\hline $\begin{array}{l}\text { Effect of the types of project overhead costs on the time performance of } \\
\text { projects }\end{array}$ & 0.184 & accept & difference not significant \\
\hline $\begin{array}{l}\text { Effect of the types of project overhead costs on the quality performance of } \\
\text { projects }\end{array}$ & 0.260 & & 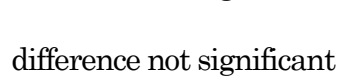 \\
\hline Effec & 0.5 & & \\
\hline Level of use of methods of allocating project overhead costs & 0.848 & accept & difference not significant \\
\hline
\end{tabular}

project overhead costs on the performance of a project (using cost, time, and quality criteria), the three research hypotheses earlier stated were tested using Mann-Whitney $U$ test at $p \leq 0.05$ since the measurement were obtained on ordinal or ranking scale. The rule for the rejection or non-rejection of the hypothesis is that if $\mathrm{p}$-value $>0.05$, the test fails to reject the hypothesis but if $p$-value $\leq 0.05$, the test rejects the hypothesis. The results are presented in Table 7.

The results of the Mann Whitney U test presented in Table 7 shows that the cases compared had p-values of $0.729,0.184,0.260,0.590$ and 0.848 respectively, all values $\geq 0.05$ implies acceptance of the hypotheses that there is no significant difference between the perception of small and medium size contractors.

The result in Table 7 shows that there is no significant difference in the perceptions of small and medium size contractors, concerning the effect of the types of project overhead costs on the cost, time and quality performance of projects. The study also shows that there is no difference in the perception of the categories of contractors concerning the relative effect of project overhead allocation factors on overhead costs and the level of use of methods of allocating project overhead costs. The agreement in perception may be attributable to the fact that the scope, objectives and managerial capabilities of the firms may not differ significantly making them to reason and act alike in the industry.

\section{Conclusion and Recommendations}

The study had made efforts to evaluate the effect of amount of various types of project overhead costs on performance of public building projects; evaluate the effect of project overhead allocation factors on overhead costs of public building projects, and evaluate the level of use of methods by companies to allocate and estimate overhead costs among small and medium size contractors in South-South zone of Nigeria.

The study has revealed that there are great similarities in the operation and perception of small and medium size contractors in the zone. Supervision costs, cost of rework, equipment management costs, general field expenses and temporary works and services costs were found to be prominent overheads costs that their amount affect cost, time and quality performance of projects. Type, size and policy of construction firm, size and complexity of the project, location of project, payment schedule and nature and type of the contract are the top five factors affecting the amount of project overheads in the area. The study recommends that contractors should lay more priority on the values of the identified types of overheads that affect performance as well as the factors observed to significantly affect the amount of project overhead costs in their efforts to accurately allocate and manage project overhead costs. It is also recommended that contractors in the study area should encourage the use of other allocation methods like Activity-Based Costing and compare the results to be observed. The study has only evaluated the perception of some contractors on the extent of influence of the various types of project overhead cost on project performance, therefore further studies can be carried out by estimating the magnitude and effect of the various types of project overhead costs. This study has only evaluated the effect of the factors on project overhead costs in general and not on each of the overhead cost, therefore it is also suggested that further research can be carried out on the effect of the factors on each project overhead cost to further assist stakeholder in decision which can enhance project performance.

\section{References}

1. Ayangade, J.A., Wahab, A.B., and Alake, O., An Investigation of the Performance of Due Process Mechanism in the Execution of Construction Projects in Nigeria, Civil Engineering Dimension, 11(1), March 2009, pp.1-7.

2. Assaf, S.A., Bubshait, A.A., Atiyah, S., and AlShahri, S., Project Overhead Costs in Saudi Arabia, Cost Engineering Journal, 41(4), 1999, pp. 33-38.

3. Chao, L.C., Estimation of Contractor's Project Overhead Rate as Research on Building Cost, Proceedings from International Conference on Building Education and Research (BEAR) "Building Resilience", 11-15 February 2008, Taiwan, pp. 74-82 http://www.irb.fraunhofer. de/ CIBlibrary/ 
4. Assaf, S.A., Bubshait, A.A., Atiyah, S., and AlShahri, S., The Management of Construction Company Overhead Costs, International Journal of Project Management, 19(5), 2001, pp. 295-303.

5. Holland, N. and Hobson, D., Indirect Cost Categorization and Allocation by Construction Contractors, Journal of Architectural Engineering, ASCE, 5(2), 1999, pp. 49-56.

6. Dagostino, F.R., Estimating in Building Construction, Prentice-Hall, New Jersey, 1989.

7. Chitkara, K.K., Construction Project Management. Planning, Scheduling and Controlling, $11^{\text {th }}$ ed., Tata McGraw Hill Publishing Company Limited, New Delhi, 2006.

8. Al-Shahri, M.H., Overhead Costs in Building Construction in Saudi Arabia, Masters Thesis King Fahd University of Petroleum and Mineral, Dhahran, Saudi Arabia, 1997, Retrieved from; http://eprints.kfupm.edu.sa/10349.

9. Tishlias, D., How to Measure Your Organization's Efficiency, Nonprofit World, 10(3), 1992, pp. 27-31.

10. Oyewobi, L.O., Ibironke, O.T., Ganiyu, O., and Ola-Awo, A.W., Evaluating Rework Cost- A Study of Selected Building Projects in Niger State, Nigeria Journal of Geography and Regional Planning, 4(3), March 2011, pp. 147-151.

11. Ogunsemi, D.R. and Aje. I.O., A Model for Contractors' Selection in Nigeria, Journal of Financial Management of Property and Construction, 11(1), 2006, pp. 33-44.

12. Taylor, G.R., The Importance of Estimating OH, Cost Engineering (AACE), 36(2), 1994, pp. 15-18.

13. Adrian, J.J., Construction Estimating, Reston Pub.co., Reston, VA, 1982.

14. El-Sawy, I.Y., Razek, M.A., and Hosny, H.E., Factors Affecting Site Overhead Cost for Building Construction Projects, Journal of Al Azhar University Engineering Sector (JAUES), Issue 3, 2010.

15. Udechukwu, F. N., Survey of Small and Medium Scale Industries and Their Potentials in Nigeria, Seminar on Small and Medium Industries Equity Investments Scheme (SMIEIS), Publication of Central Bank of Nigeria (CBN) Training Centre, Lagos No. 4, 2003.

16. Onugu, B.A.N., Small and Medium Enterprises (SMES) in Nigeria: Problems and Prospects, Unpublished Ph.D Dissertation in Management, St. Clements University, Australia, 2005.
17. Ujene, A.O., Dynamics of Direct Costs of Building Elements in South-South, Nigeria, Unpublished Ph.D Thesis in Construction Management, Department of Building, University of Uyo, Nigeria, 2012.

18. Fagbenle, O.I., The Effect of Non Monetary Incentives on the Performance of Construction Craftsmen in Nigeria, RICS COBRA Research Conference, University of Cape Town, 10-11th September, 2009, pp. 737-753.

19. Ikpe, E.O., Development of Cost Benefit Analysis Model of Accident Prevention on Construction Projects, Unpublished Ph.D thesis, University of Wolverhampton, 2009.

20. Takim, R. and Akintoye, A., Performance Indicators for Successful Construction Project Performance, In: Greenwood, D (Ed.), 18 th Annual ARCOM Conference, 2-4 September, University of Northumbria. Association of Researchers in Construction Management, Vol. 2, 2002, pp. 545-555.

21. Fagbenle, O.I. and Oluwunmi, A.O., Building Failure and Collapse in Nigeria: The Influence of the Informal Sector, Journal of Sustainable Development, 3(4), December 2010, pp. 268-278.

22. Nicholas, J.M., Project Management for Business and Technology; Principles and Practice, $2^{\text {nd }}$ ed., Prentice Hall of India Private Limited, New Delhi, 2006.

23. Nega, F., Causes and Effects of Cost Overrun on Public Building Construction Projects in Ethiopia, M.Sc Thesis, Construction Technology and Management, Addis Ababa University, Ethiopia, 2005.

24. Omofonmwa, S.I. and Odia, L.O., Oil Exploitation and Conflict in the Niger-Delta Region of Nigeria, Journal of Human Ecology, 26(1), 2009, pp. 25-30.

25. Ujene, A. O. and Achuenu, E., Stress among Building Construction Craftsmen in Some Cities of the South-South Geo-Political Zone of Nigeria, Journal of Environmental Design, 2(1), September 2006, pp. 72-90.

26. Ekpo, I.V., Ibok, P.S., Eminimoh, E.J., Jacob, E., and Udo-Ekpo, V.P., Universal Basic Education and Socio-Economic Prospects of the Girl-Child in South-South Nigeria, Report of Research Financed by Education Research Network for West and Central Africa (ERNWACA) with project support from UEMOA Regional Centre of Excellence and the Ministry of Foreign Affairs of the Netherlands, 2009. 
27. Federal Republic of Nigeria Official Gazette, Report on the Census 2006 Final Results, 96(2): B1-B3, February, 2009.

28. International Crisis Group. Nigeria: Seizing the Moment in the Niger Delta. Crisis Group Africa Briefing No60, 30 April. 2009, pp.1-20.

29. Pallant, J., SPSS Survival Manual, A Step by Step Guide to Data Analysis Using SPSS for Windows, (3rd ed.), Berkshire: McGraw Hill Companies, 2007.
30. Rezaian, A., Time-Cost-Quality-Risk of Construction and Development Projects or Investment, Middle-East Journal of Scientific Research 10 (2), 2011, pp. 218-223.

31. El-Sawy, I.Y., Hosny, H.E., and Razek, M.A., A Neural Network Model for Construction Project Site Overhead Cost Estimating in Egypt, International Journal of Computer Science Issues (IJCS), 8(3), 2011, pp. 273-283. 